\title{
Correction to: Prevention of hypermelanosis by rearing Japanese flounder Paralichthys olivaceus in net-lined tanks
}

\author{
Koei Mizutani ${ }^{1,5} \cdot$ Toshiyuki Yamada $^{2} \cdot$ Keita W. Suzuki $^{3} \cdot$ Reiji Masuda $^{3} \cdot$ Kuniaki Nakata $^{4,6} \cdot$ Masatomo Tagawa $^{4} \mathbb{C}$
}

Published online: 1 April 2021

(c) The Author(s) 2021

\section{Correction to: Fisheries Science (2020) 86:127-136 https://doi.org/10.1007/s12562-019-01369-1}

The article "Prevention of hypermelanosis by rearing Japanese flounder Paralichthys olivaceus in net-lined tanks", written by Koei Mizutani, Toshiyuki Yamada, Keita W. Suzuki, Reiji Masuda, Kuniaki Nakata and Masatomo Tagawa was originally published Online First without Open Access. After publication in volume 86, issue 1, page 127-136 the author decided to opt for Open Choice and to make the article an Open Access publication. Therefore, the copyright of the article has been changed to $(9)$ The Author(s) 2021 and the article is forthwith distributed under the terms of the Creative Commons Attribution 4.0 International License (https://creativecommons.org/licenses/by/4.0/), which permits use, sharing, adaptation, distribution and reproduction in any medium or format, as long as you give appropriate credit to the original author(s) and the source,

The original version of this article was revised due to a retrospective Open Access order.

The original article can be found online at https://doi.org/10.1007/ s12562-019-01369-1.

\section{Masatomo Tagawa}

tagawa@kais.kyoto-u.ac.jp

Koei Mizutani

mizutani31@ pref.kyoto.lg.jp

Toshiyuki Yamada

yamadat@pref.nagasaki.lg.jp

Keita W. Suzuki

suzuki.keita.3r@kyoto-u.ac.jp

Reiji Masuda

reiji@kais.kyoto-u.ac.jp

Kuniaki Nakata

nakata@iwatani.co.jp

1 Department of Bioresource Science, Faculty of Agriculture, Kyoto University, Kitashirakawa, Sakyo, Kyoto 606-8502, Japan provide a link to the Creative Commons licence, and indicate if changes were made. The original article has been corrected.

Open Access This article is licensed under a Creative Commons Attribution 4.0 International License, which permits use, sharing, adaptation, distribution and reproduction in any medium or format, as long as you give appropriate credit to the original author(s) and the source, provide a link to the Creative Commons licence, and indicate if changes were made. The images or other third party material in this article are included in the article's Creative Commons licence, unless indicated otherwise in a credit line to the material. If material is not included in the article's Creative Commons licence and your intended use is not permitted by statutory regulation or exceeds the permitted use, you will need to obtain permission directly from the copyright holder. To view a copy of this licence, visit http://creativecommons.org/licenses/by/4.0/.

Publisher's Note Springer Nature remains neutral with regard to jurisdictional claims in published maps and institutional affiliations.

2 Nagasaki Prefectural Institute of Fisheries, Taira, Nagasaki, Nagasaki 851-2213, Japan

3 Field Science Education and Research Center, Maizuru Fisheries Research Station, Kyoto University, Nagahama, Maizuru, Kyoto 625-0086, Japan

4 Division of Applied Biosciences, Graduate School of Agriculture, Kyoto University, Kitashirakawa, Sakyo, Kyoto, Kyoto 606-8502, Japan

5 Present Address: Fisheries Office of Kyoto Prefecture, Odashukuno, Miyazu, Kyoto 626-0052, Japan

6 Present Address: Iwatani Corporation, Hommachi 3-6-4, Chuo-ku, Osaka, Osaka 541-0053, Japan 